Original Article

\title{
Effect of calcium on Pseudomonas aeruginasa and Bacillus cereus metabolites
}

\author{
Efeito do cálcio nos metabólitos de Pseudomonas aeruginasa e Bacillus cereus
}

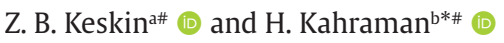 \\ anonu University, Institute of Science, Department of Biology, Malatya, Turkey \\ bInonu University, Faculty of Art and Science, Department of Biology, Malatya, Turkey
}

\begin{abstract}
The effects of Calcium $\left(\mathrm{Ca}^{+2}\right)$ on virulence and some parameters should be analyzed in this study. Pseudomonas aeruginosa Gram (-) and Bacillus cereus Gram (+) were used. Both bacteria are soil bacteria. In this study; the effect of $\mathrm{Ca}^{+2}$ on protease, amylase, LasB elastolytic assay, $\mathrm{H}_{2} \mathrm{O}_{2}$, pyorubin and biofilm on metabolites of these bacteria were investigated during 24 hour time. In this study, the effect of $\mathrm{Ca}^{+2}$ on the production of some secondary metabolites on P. aeruginosa and B. cereus was investigated and presented for the first time by us.
\end{abstract}

Keywords: calcium, Bacillus cereus, Pseudomonas aeruginosa, seconder metabolite.

\section{Resumo}

Os efeitos do cálcio $\left(\mathrm{Ca}^{+2}\right)$ na virulência e alguns parâmetros devem ser analisados neste estudo. Pseudomonas aeruginosa Gram (-) e Bacillus cereus Gram (+) foram usados. Ambas as bactérias são bactérias do solo. Neste estudo, o efeito do $\mathrm{Ca}^{+2}$ sobre a protease, amilase, ensaio elastolítico LasB, $\mathrm{H}_{2} \mathrm{O}_{2}$, piorubina e biofilme nos metabólitos dessas bactérias foram investigados durante 24 horas. Neste estudo, o efeito do $\mathrm{Ca}^{+2}$ na produção de alguns metabólitos secundários em $P$. aeruginosa e B. cereus foi investigado e apresentado pela primeira vez por nós.

Palavras-chave: cálcio, Bacillus cereus, Pseudomonas aeruginosa, metabólito seconder.

\section{Introduction}

$\alpha$-amylase (E.C.3.2.1.1; 1,4- $\alpha$-D-glucanglucanohydrolase) is a hydrolytic enzyme that hydrolyzes $\alpha-1,4$-glycosidic linkages in starch and forms products such as glucose or maltose. This enzyme is one of the most important biotechnological products used in various industrial processes such as food, paper, textile and detergent (Liu and $\mathrm{Xu}, 2008$ ).

$\alpha$-amylase can be isolated from plants, animals or microorganisms. It is found in many bacteria (Bacillus spp. (B. amyloliquefaciens, B. subtilis, B. cereus, B. amyloloquefaciens, B. amloloquefaciens, B. megaterium, B. licheniformis, Lactobacillus sp, Escherichia sp, Proteus sp, Clostridium sp and Pseudomonas sp.) and fungi (Aspergillus, Penicillum, Sefalosporium, Neurospora and Rhizopus). Microorganisms in particular, are used more in the production of this enzyme. Bacillus species are more widely used in commercial protease production (Parmar and Pandya, 2012; Venkata and Divakar, 2013; Khannous et al., 2014; Sundarram and Murthy, 2014; Keharom et al., 2016; Özcan and Çorbaci, 2017).

$P$. aeruginosa is a metabolically versatile Gram (-) pathogenic bacterium that has adapted to many environments associated with terrestrial, aquatic, animal, human and plants. In addition, Pseudomonas species are bacterial groups with many scientific and technological importances. It is a metabolically versatile and powerful organism that can use many simple or complex organic compounds. Pseudomonas has a fairly large genome in its genes that contains many different virulence factors. In this way, it has the ability to adapt to almost any environment. As a result of processes such as phase variation or adaptive mutations to changing environmental conditions, rapid change of the $P$. aeruginosa genotype is possible in producing morphologically different phenotypic variants. Pseudomonas sp. is capable of producing many extracellular enzymes such as lipase and amylase. Proteases secreted, play an important role in pathogenesis during acute infections. Apart from this, P. aeruginosa can produce LasB elastase and LasA staphylolytic protease secretion (Kessler et al., 1993; Kong et al., 2005; Hosseinidoust et al., 2013; Jiménez et al., 2015; Georgescu et al., 2016; Kalaiarasan and Narasimha, 2016; Marou et al., 2016).

Metalloproteinase elastase A, which belongs to Pseudomonas, has been reported to break down the elastin

*e-mail: huseyin.kahraman@inonu.edu.tr

\#These two authors contribute to this work equally.

Received: September 4, 2020 - Accepted: November 23, 2020 
and increase the substrate range of elastase B. Elastase B and alkaline protease specifically destroy host defense proteins. This is very important in virulence (Caballero et al., 2001). Elastase has three active amino acids. These are the catalytic triads that work together; aspartate, histidine and serine. Elastase, E. coli and other Gram (-) bacteria outer membrane elastase, also have the property of breaking down Shigella virulence factors, which can be done by carboxy of small and hydrophobic amino acids such as glycine, alanine and valine (Vijay et al., 2014).

The structures we call biofilms are actually a group of microorganisms attached to a surface and covered with an exopolysaccharide matrix. It is most commonly created by $P$. aeruginos. The presence of chemotaxis, motility, surface adhesions and surfactants towards the surface are factors affecting biofilm formation (Bose et al., 2009). Biofilm, in phytopathogenic microorganisms and animal pathogens, adaptation promotes survival. Cells in biofilm are said to be more resistant to oxidative stress than free cells (Zhang et al., 2018).

Bacillus cereus can be found widely in soil and plants. Bacteria possessing psychrotrophic, spore, Gram (+), flagella, aerobic, and peritric flagels are aerobic. Optimum growing is usually $30^{\circ} \mathrm{C}$. B. cereus has lecithinase, gelatinase, amylase and protease activity. It can reduce nitrate and is resistant to polymyxin. Many strains can also breed in 7.5\% salt. Cereus takes its name from cereal, which means grain (Kalkan and Halkman, 2006).

Piyorubin is a bright red color phenazine pigment produced by some $P$. aeruginosa strains, insoluble in chloroform and soluble in water. It is irreversibly discolored at low oxygen concentration. It is red in all pH grades (Ogunnariwo and Hamilton-Miller, 1975; Hosseinidoust et al., 2013; Kalaiarasan and Narasimha, 2016; Lo et al., 2016; Marou et al., 2016).

Studies suggest that cellular $\mathrm{Ca}^{+2}$ in a host can be an environmental clue for opportunistic bacteria and can trigger their virulence. As already known, $\mathrm{Ca}^{+2}$ in prokaryotes has roles in many physiological events such as spore formation, motility, cell differentiation, transport and virulence (Guragain et al., 2013).

In this study, it was aimed to observe the effect of calcium on secondary metabolite production in two different bacteria and investigated for the first time.

\section{Materials and Methods}

\subsection{Reagents}

All chemicals were of the highest purity available commercially.

\subsection{Microorganism}

P. aeruginosa (ATCC 27853) and B. cereus (ATCC 10876) obtained from the ATCC and used this study.

\subsection{Growth conditions}

Microorganisms were grown and cultivated as follows: $3 \mathrm{~mL}$ of $24 \mathrm{~h}$ bacterial inoculum $\left(\mathrm{OD}_{600}=0.3-0.4\right)$ was inoculated into $5 \mathrm{~mL}$ growth Nutrient Broth media and agitated at the rate of static for $24 \mathrm{~h}$ at $37{ }^{\circ} \mathrm{C}$. Crude extracellular enzyme solutions were prepared by removing the cells by centrifugation at $13.500 \mathrm{rpm}$ and room temperature for $5 \mathrm{~min}$. Supernatant harvested was assayed. The concentrations of calcium based in preliminary experiments; in NB was 0,05 M, 0,15 M and 0,15 M were used in Nutrient Broth.

\subsection{Amylase activity assays}

The amount of the reducing sugars released by the action of amylases on starch was currently performed at $37{ }^{\circ} \mathrm{C}$ and $\mathrm{pH} 7$ phosphate buffer for $15 \mathrm{~min}$ and the increase in the glucose was determined by antron method. The reaction mixture contained $0.5 \mathrm{~mL}$ starch $(2 \%$ in $0.01 \mathrm{M} \mathrm{mM}$ phosphate buffer) and the $0.5 \mathrm{~mL}$ enzyme solution in a final volume of $1 \mathrm{~mL}$. One unit of amylase was defined as the amount of enzyme, required to produce reducing sugars equivalent to $1 \mu \mathrm{mol}$ glucose $/ \mathrm{min}$ at $37^{\circ} \mathrm{C}$ and at pH 7.0 (Geok et al., 2003; Venkata and Divakar, 2013).

\subsection{Pyorubin}

Bacteria were incubated at $37^{\circ} \mathrm{C}$ with static for $24 \mathrm{~h}$. The pigments in the bacterial culture were extracted with chloroform. After centrifugation, the reaction mixture contained $1 \mathrm{~mL}$ supernatan and $1.5 \mathrm{~mL}$ chloroform added. The chloroform layer was mixed with $0.5 \mathrm{~mL}$ of $0.2 \mathrm{~N} \mathrm{HCl}$, which yielded a pink solution and the absorbance, was measured at $\mathrm{OD}_{525}$. Similarly, the $\mathrm{OD}_{525}$ of the aqueous phase was alsomeasured and normalized to indicate pyorubin production per cell (Hosseinidoust et al., 2013; Kalaiarasan and Narasimha, 2016; Lo et al., 2016; Marou et al., 2016).

\subsection{Assay of protease activity}

The overnight culture of $P$. aeruginosa and $B$. cereus isolates was inoculated in Nutrient Broth. Protease activity was measured by some modification of the reaction mixture consisted of $1.0 \mathrm{~mL}$ enzyme solution preincubated at $37^{\circ} \mathrm{C}$ for $10 \mathrm{~min}$. The reaction was started by the addition of 1.0 $\mathrm{mL}$ casein $6.5 \mathrm{mg} / \mathrm{mL}$ (in $0.05 \mathrm{M}$ phosphate buffer $\mathrm{pH} 7.0$ ). The reaction mixture was then incubated in the incubator at $37^{\circ} \mathrm{C}$ for $10 \mathrm{~min}$ shaker and terminated by the addition of $1 \mathrm{~mL} \mathrm{10 \%} \mathrm{trichloroacetic} \mathrm{acid} \mathrm{(TCA).} \mathrm{A} \mathrm{vortex} \mathrm{mixer}$ was used. This mixture was further incubated at $37{ }^{\circ} \mathrm{C}$ for $20 \mathrm{~min}$, followed by centrifugation at 13,500 rpm for $10 \mathrm{~min}$. The supernatant was harvested. To $300 \mu \mathrm{L}$ supernatant, $750 \mu \mathrm{L}$ of $0.5 \mathrm{M} \mathrm{Na}_{2} \mathrm{CO}_{3}$ and $150 \mu \mathrm{L}$ folin ciocalteau reagent: water $(1: 3 \mathrm{v} / \mathrm{v})$ was added to yield a blue color. The colored mixture was incubated in an incubator at $37{ }^{\circ} \mathrm{C}$ for $20 \mathrm{~min}$. Absorbance was read at $\mathrm{OD}_{660} \mathrm{~nm}$. The amount of tyrosine was determined from the tyrosine standard curve (Geok et al., 2003; Özcan and Çorbaci, 2017; Fitriani and Güven, 2018).

\subsection{Biofilm assay}

Biofilm generated by $P$. aeruginosa was evaluated using the following crystal violet assay (Jiménez et al., 2015). The biofilm forming ability isolates were tested using glass tube with little modifications. The overnight 
culture of $P$. aeruginos $a$ isolates were inoculated in Nutrient Broth supplemented with $\mathrm{Ca}^{+2}(0 ; 0.05 ; 0.1$ and $0.15 \mathrm{M})$ for 24 hours at $37{ }^{\circ} \mathrm{C}$. After incubation, removing the planktonic bacteria, the wells were carefully rinsed three times-distilled water and then stained with $0.1 \%$ of crystal violet (10 minutes, at room temperature) and washed with distilled water (three-times). After air drying, ethanol (95\%) was added and incubated for $15 \mathrm{~min}$ to remove the bound crystal violet. The absorbance was measured spectrophotometrically at $\mathrm{OD}_{570} \mathrm{~nm}$, for quantification of biofilm biomass (Jiménez et al., 2015; Kalaiarasan and Narasimha, 2016; Mirani et al., 2018; Zhang et al., 2018).

\subsection{LasB elastolytic assay}

Liquid cultures were inoculated on Starch Agar plates. The test was performed with some modifications. $1 \mathrm{~mL}$ supernatan, $1 \mathrm{~mL}$ reaction mixture [ $1 \mathrm{mg} / \mathrm{mLECR}$ in $200 \mathrm{mM}$ Trizma-base buffrer ( $\mathrm{pH} \mathrm{8.8)]} \mathrm{and} \mathrm{then} \mathrm{incubated} \mathrm{with}$ shaking at $37^{\circ} \mathrm{C}$ for $30 \mathrm{~min}$. Then $0.5 \mathrm{~mL} 100 \mathrm{mM}$ EDTA added and reaction stopped. Insoluble ECR was removed by centrifugation (6000 rpm and room temperature $5 \mathrm{~min}$ ), and the absorption of the supernatant was measured at $\mathrm{OD}_{495} \mathrm{~nm}$. Activity was expressed as change in $\mathrm{OD}_{495} \mathrm{~g} /$ protein (Kong et al., 2005; Vijay et al., 2014; Jose et al., 2017).

\section{9. $\mathrm{H}_{2} \mathrm{O}_{2}$ sensitivity assay}

The test was performed with some modifications. Liquid cultures were inoculated on Müller Hinton agar plates. Empty antibiogram discs were placed on which $4 \mathrm{ul} \mathrm{H}_{2} \mathrm{O}_{2}(30 \%)$ was added. Plates incubated for at $37^{\circ} \mathrm{C}$ and 24 hours. Then, diameter measurements were recorded (Zheng et al., 2018).

All experiments were carried out in triplicates.

\subsection{Statistics}

Data were presented as mean \pm SD. Student's t-test was used for comparing and significant difference was claimed when $P<0.05$.

\section{Results}

The determination of reducing sugars was generally carried out by the antrone method. The concentration of the glucose was determined at $\mathrm{OD}_{620} \mathrm{~nm}$ spectrophotometrically. It is mainly used in the assay of $\alpha$-amylase activity (Keharom et al., 2016). In our study, various seconder parameters of $B$. cereus and $P$. aeruginosa were investigated in solid media, and 24-hour incubation at $37{ }^{\circ} \mathrm{C}$ was evaluated. The effects of $\mathrm{Ca}^{+2}$ on virulence and some parameters were tried to be analyzed in this study. $P$. aeruginosa and B. cereus were used as Gram (-) bacteria as a control and Gram (+) bacteria as a control. Both bacteria are soil bacteria. The concentration was left at $0.15 \mathrm{M}$ because the bacteria lost its ability to reproduce in the above concentrations. A severe inhibitory effect was observed. For this reason, as they were found to be the most suitable concentrations as a result of optimization studies, $0.05,0.1$ and $0.15 \mathrm{M} \mathrm{Ca}^{+2}$ were used.
Why did $P$. aeruginosa compare with $B$. cereus? a) Both are soil bacteria; b) $P$. aeruginosa Gram (-) and B. cereus $\operatorname{Gram}(+)$. Therefore, it gives the opportunity to compare; c) $P$. aeruginosa sporeless and $B$. cereus sporulated bacteria; d) Pathogenicity levels are different. e) We used our work in this preference.

\subsection{Amylase activity}

The determination of reducing sugars was generally carried out by the antrone method. The concentration of the glucose was determined at $\mathrm{OD}_{620} \mathrm{~nm}$ spectrophotometrically. It is mainly used in the assay of $\alpha$-amylase activity (Keharom et al., 2016). Amylase activity, in the presence of $\mathrm{Ca}^{+2}$, B. cereus, achieved a maximum increase of up to 1.2 times. The highest increase was in the presence of $0.15 \mathrm{M} \mathrm{Ca}^{+2}$ with $25.32 \mathrm{U} / \mathrm{mL}$. For P. aeruginosa, an increase of 1.6 times more amylase activity was observed on average compared to B. ceres. When P. aeruginosa was evaluated in itself, no significant increase was observed in the presence of $\mathrm{Ca}^{+2}$. The highest P. aeruginosa amylase activity was observed in the presence of $0.1 \mathrm{M}$ Ca with $32.13 \mathrm{U} / \mathrm{mL}$. Although P. aeruginosa is more advantageous on the graph, in its production it caused a $102 \%$ increase in $0.1 \mathrm{M} \mathrm{Ca}^{+2}$ concentrations. However, this ratio in B. cereus caused an increase in $123 \%$ amylase production in the presence of $0.15 \mathrm{M} \mathrm{Ca}^{+2}$. All of these values are calculated according to the controls (Figure 1).

\subsection{Biofilm activity}

As was expected, biofilm formation in B. cereus was low. The highest biofilm formation occurred in $\mathrm{OD}_{570}$ with 0.284 in the presence of $0.1 \mathrm{M} \mathrm{Ca}^{+2}$ for B. cereus. According to the control, an increase of up to 2.5 times was observed in the presence of $\mathrm{Ca}^{+2}$. In $P$. aeruginosa, a higher biofilm formation occurred, as was expected. Unlike B. cereus, in the presence of $0.1 \mathrm{M} \mathrm{Ca}^{+2}$, a higher biofilm formation was observed in $\mathrm{OD}_{570}$ with 0.735 . It appears to be the most suitable concentration for biofilm formation for $P$. aeruginosa. The difference was two times more than in the control and there was approximately three times more biofilm formation than in $B$. cereus. Although $P$. aeruginosa is advantageous, a $200 \%$ increase in $0.1 \mathrm{M} \mathrm{Ca}^{+2}$ concentrations was observed compared to the control. However, this ratio in B. cereus caused a $252 \%$

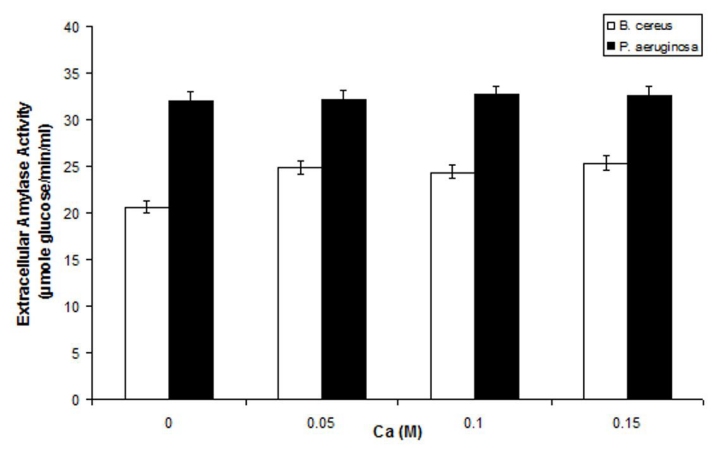

Figure 1. Amylase unit activity of $B$. cereus $(O)$ and $P$. aeruginosa $(\bullet)$, grown in NB medium under static conditions at $37^{\circ} \mathrm{C}$. 
increase in the presence of $0.15 \mathrm{M} \mathrm{Ca}^{+2}$ compared to the control (Figure 2).

\subsection{LasB activity (ECR)}

The addition of $\mathrm{Ca}^{+2}$ in both bacteria decreased ECR activity. There was a decrease of 7.14 times in B. cereus and 4.8 times in P. aeruginosa. It occurred mostly in B. cereus. The greatest decrease in both bacteria occurred in the presence of $0.15 \mathrm{M} \mathrm{Ca}^{+2}$. In accordance with $B$. cereus, ECR activity decreased 1.7 times more than with $P$. aeruginosa. The graphic here shows a harmonious decrease (Figure 3 ).

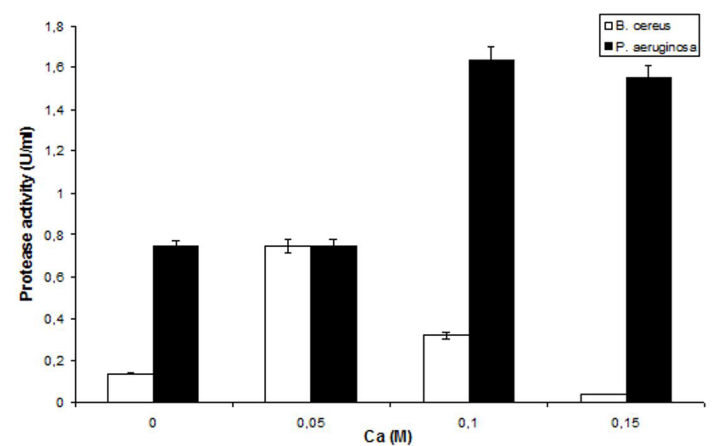

Figure 2. Biofilm levels of B. cereus $(O)$ and $P$. aeruginosa $(\bullet)$, grown in NB medium under static conditions at $37^{\circ} \mathrm{C}$.

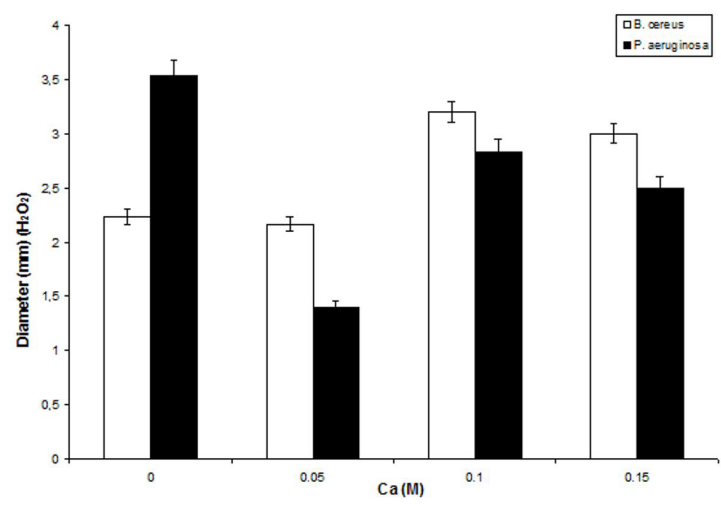

Figure 3. Las $B$ activity of $B$. cereus $(O)$ and $P$. aeruginosa $(\bullet)$, grown in NB medium under static conditions at $37^{\circ} \mathrm{C}$.

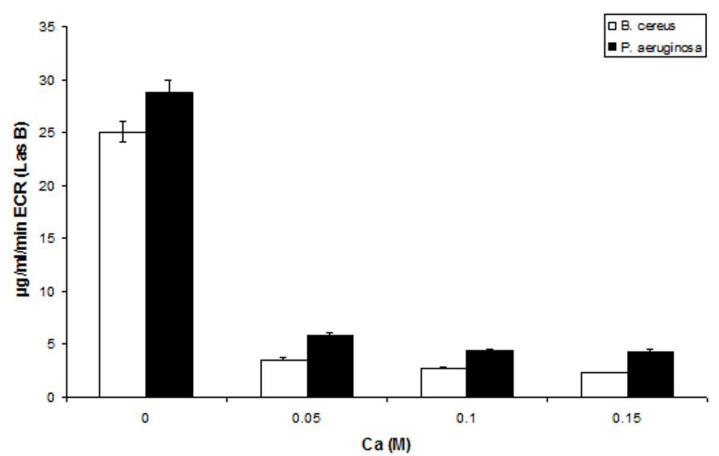

Figure 4. $\mathrm{H}_{2} \mathrm{O}_{2}$ diameter of $B$. cereus $(\mathrm{O})$ and $P$. aeruginosa grown in NB medium under static conditions at $37^{\circ} \mathrm{C}$.

\section{4. $\mathrm{H}_{2} \mathrm{O}_{2}$}

In $B$. cereus, the highest sensitivity was observed in the presence of $0.15 \mathrm{M} \mathrm{Ca}^{+2}$ with $33 \mathrm{~mm} . \mathrm{H}_{2} \mathrm{O}_{2}$ resistance only increased compared to the control in the presence of $0.05 \mathrm{M} \mathrm{Ca}^{+2}$. This was observed with a $7 \mathrm{~mm}$ zone decrease. While P. aeruginosa was $35.3 \mathrm{~mm}$ in the highest zone control, the highest resistance was realized in the presence of $0.1 \mathrm{M} \mathrm{Ca}^{+2}$, just like in $B$. cereus. This was observed with a zone diameter of $14 \mathrm{~mm}$. Resistance increase in both bacteria was observed in the presence of $0.05 \mathrm{M} \mathrm{Ca}^{+2}$. An increase in sensitivity started to occur above these concentrations. While $\mathrm{Ca}^{+2}$ increase in $\mathrm{B}$. cereus causes a sensitivity increase compared to the control, in $P$. aeruginosa, resistance increased continuously compared to the control. $\mathrm{H}_{2} \mathrm{O}_{2}$ resistance in $P$. aeruginosa caused an increase in resistance in all three concentrations compared to the control (Figure 4). P. aeruginosa increased by $60 \%$ resistance at a concentration of $0.05 \mathrm{M} \mathrm{Ca}^{+2}$. However, this ratio in $B$. cereus caused only a $3 \%$ increase in the presence of $0.05 \mathrm{M} \mathrm{Ca}^{+2}$. These values are calculated according to the controls.

\subsection{Protease activity}

The presence of $\mathrm{Ca}^{+2}$ in both bacteria caused an increase in protease activity. This increase caused enzyme activity in $B$. cereus in the presence of $0.05 \mathrm{M} \mathrm{Ca}^{+2}$ up to $0.746 \mathrm{U} / \mathrm{mL}$ and up to 5.6 times according to the control. Therefore, this appears to be the most appropriate concentration in protease activity for $B$. cereus. In $P$. aeruginosa, only a 2.3-fold increase in the presence of $\mathrm{Ca}^{+2}$ was $1.635 \mathrm{U} / \mathrm{mL}$ in the presence of $0.1 \mathrm{M} \mathrm{Ca}^{+2}$. Consequently, this appears to be the most appropriate concentration in protease activity for $P$. aeruginosa. However, the concentration of $0.15 \mathrm{M} \mathrm{Ca}^{+2}$ caused a decrease in both bacteria. In general, the presence of $\mathrm{Ca}^{+2}$ increased protease activity. Although $P$. aeruginosa is advantageous when the graph is examined, it caused an increase of $0.1 \% \mathrm{Ca}^{+2}$ concentrations by $220 \%$. However, this ratio in B. cereus caused a $548 \%$ increase in the presence of $0.05 \mathrm{M} \mathrm{Ca}^{+2}$. These values are calculated according to the controls (Figure 5).

\subsection{Pyorubin activity}

Pyorubin, a pigment, caused an increase in the presence of $\mathrm{Ca}^{+2}$. However, these increases are not seen as significant

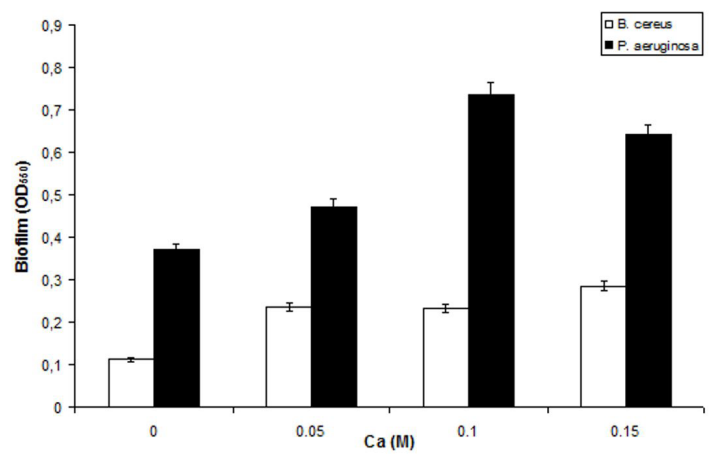

Figure 5. Protease activity of $B$. cereus $(O)$ and $P$. aeruginosa $(\bullet)$, grown in NB medium under static conditions at $37^{\circ} \mathrm{C}$. 


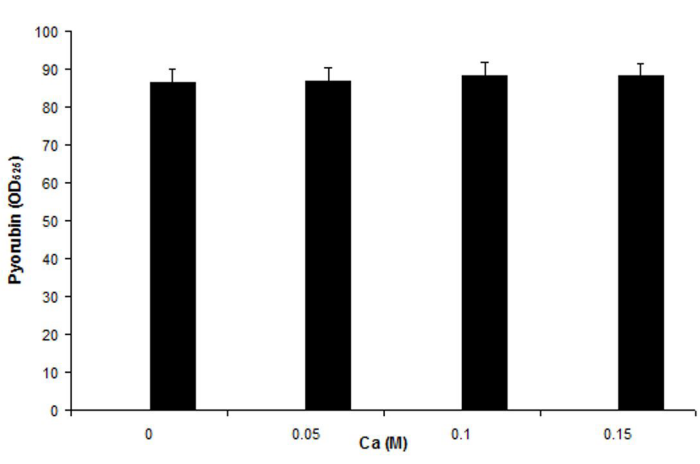

Figure 6. Pyorubin production of P. aeruginosa $(\bullet)$, grown in NB medium under static conditions at $37^{\circ} \mathrm{C}$.

increases. Subsequent concentrations, the highest in the presence of $0.1 \mathrm{M} \mathrm{Ca}^{+2}$, also began to decline. The value of 88.21 was obtained. As a result, $\mathrm{Ca}^{+2}$ had no effect on the increase or decrease of pyorubin. As a result, it increased the production of $0.1 \mathrm{M} \mathrm{Ca}^{+2}$ pyorubin, which has the highest effect, by only $102 \%$ (Figure 6 ). Why are there no $B$. cereus values in this figure? Because of pyorubin is a metabolite specific to $P$. aeruginosa. Therefore, it is not shown on the figure.

\section{Discussion}

The determination of reducing sugars was generally carried out by the antrone method. The concentration of the glucose was determined at $\mathrm{OD}_{620} \mathrm{~nm}$ spectrophotometrically. It is mainly used in the assay of $\alpha$-amylase activity (Keharom et al., 2016). In some studies, it has been observed that calcium ion influences the biofilm structure in $P$. aeruginosa cultures. They stated that by adding calcium it was 10 to 20 times thicker than the formation of non-added calcium biofilm (Sarkisova et al., 2005; Cruz et al., 2012). The extracellular elastase (LasB) and LasA amounts, which are the products of the Type II secretory pathway, increase in the presence of additional calcium. In addition, the amount of extracellular protease increased with the addition of $\mathrm{Ca}^{+2}$ (Sarkisova et al., 2005). Another study showed a 20 -fold increase in biofilm thickness after 24 hours in the presence of $\mathrm{Ca}^{+2}$ (1.0 and $10.0 \mathrm{mM} \mathrm{CaCl}$ ). In this study, by growing the culture with $10 \mathrm{mM} \mathrm{CaCl}_{2}$, approximately two to three times more biofilm structures were observed compared to the non- $\mathrm{Ca}^{+2}$ medium (Sarkisova et al., 2005). Some studies have stated that the amount of protease and pyocyanin increase with the addition of $\mathrm{Ca}^{+2}$. The addition of calcium has been shown to increase the biofilm structure in Vibrio cholerae. Although, in Pectobacterium carotovorum, it has been found to increase the activity of the type III secretion system and the expression of effector proteins, as well as the modulation of hydrolytic enzymes (such as polygalacturonase and pectate lyase), which are considered to be important in virulence. Calcium also plays a role in $X$. fastidiosa infection. In addition, the presence of $\mathrm{Ca}^{+2}$ is said to increase biofilm formation, cell binding and motility in vitro. These results show that the role of
$\mathrm{Ca}^{+2}$ in biofilm formation is important (Sarkisova et al., 2005; Cruz et al., 2012). It is also stated in Prokaryotes that the presence of $\mathrm{Ca}^{+2}$ regulates and increases bacterial gene expression. Many prokaryotes, including Escherichia coli, Propionibacterium acnes, Streptococcus pneumoniae, Bacillus subtilis and Cyanobacteria, have also been shown to maintain intracellular $\mathrm{Ca}^{+2}$ levels at micromolar levels, producing in response to environmental and physiological conditions. This suggests that $\mathrm{Ca}^{+2}$ plays an important role in prokaryotic physiology and virulence. Apart from this, it is stated that $\mathrm{Ca}^{+2}$ increases biofilm formation in $P$. aeruginosa and protease, and pyocyanin virulence factors induce biosynthesis (Guragain et al., 2013; Domínguez et al., 2015). In addition, it has been stated in a study that the presence of $\mathrm{Ca}^{+2}$ in the environment increases the expression of genes that cause proteolysis and stress response (Guragain et al., 2013). In another study, the presence of $\mathrm{Ca}^{+2}$ has been shown to increase the virulence of $P$. aeruginos and the thickness of the biofilm structure. It also shows that $\mathrm{Ca}^{+2}$, X. fastidiosa's biofilm formation, has the ability to cling to the cell surface and play a role in the regulation of the movement of twitches (Sarkisova et al., 2005; Cruz et al., 2012). The chemical analysis showed an increased production of pyocyanin with $\mathrm{Ca}^{+2}$ additions in P. aeruginosa FRD1 (Sarkisova et al., 2005). Chemical analysis shows that pyocyanin production increases with the addition of $\mathrm{Ca}^{+2}$ (Sarkisova et al., 2005). We did not find any study on the effect of $\mathrm{Ca}^{+2}$ on pyoverdin. It is stated that protease enzymes need some metal ions in order to maintain their stability and maintain their active form. According to this study; it has been stated that $\mathrm{Ca}^{+2}, \mathrm{Mg}^{+2}$ and $\mathrm{Mn}^{+2}$ ions increase the protease activity (Guragain et al., 2013).

\section{Acknowledgements}

This work was supported by a Grant (APYB 2019/1811) from Research Fund Unit of Inonu University, Turkey.

\section{References}

BOSE, S., KHODKE, M., BASAK, S. and MALLICK, S.K., 2009. Detection of biofilm producing Staphylococci: need of the hour.Journal of Clinical and Diagnostic Research, vol. 3, pp. 1915-1920.

CABALLERO, A.R., MOREAU, J.M., ENGEL, L.S., MARQUART, M.E., HILL, J.M. and O'CALLAGHAN, R.J., 2001. Pseudomonas aeruginosa protease IV enzyme assays and comparison to other Pseudomonas proteases. Analytical Biochemistry, vol. 290, no. 2, pp. 330-337. PMid:11237336.

CRUZ, L.F., COBINE, P.A. and DE LA FUENTE, L., 2012. Calcium increases Xylella fastidiosa surface attachment, biofilm formation and twitching motility. Applied and Environmental Microbiology, vol. 78, no. 5, pp. 1321-1331. PMid:22194297.

DOMÍNGUEZ, D.C., GURAGAIN, M. and PATRAUCHAN, M., 2015. Calcium binding proteins and calcium signaling in prokaryotes. Cell Calcium, vol. 57, no. 3, pp. 151-165. PMid:25555683.

FITRIANI, S. and GÜVEN, K., 2018. Isolation, screening, partial purification and characterization of protease from halophilic bacteria isolated from Indonesian fermented food. Anadolu 
Üniversitesi Bilim ve Teknoloji Dergisi C - Yaşam Bilimleri ve Biyoteknoloji, vol. 7, no. 2, pp. 130-142.

GEOK, L.P., RAZAK, C.N.A., ABD RAHMAN, R.N.Z., BASRI, M. and SALLEH, A.B., 2003. Isolation and screening of an extracellular organic solvent-tolerant protease producer. Biochemical Engineering Journal, vol. 13, pp. 73-77.

GEORGESCU, M., GHEORGHE, I., CURUTIU, C., LAZAR, V., BLEOTU, C. and CHIFIRIUC, M.C., 2016. Virulence and resistance features of Pseudomonas aeruginosa strains isolated from chronic leg ulcers. BMC Infectious Diseases, vol. 16, no. 92, suppl. 1, pp. 1-7. PMid:27169367.

GURAGAIN, M., LENABURG, D.L., MOORE, F.S., REUTLINGER, I. and PATRAUCHAN, M.A., 2013. Calcium homeostasis in Pseudomonas aeruginosa requires multiple transporters and modulates swarming motility. Cell Calcium, vol. 54, no. 5, pp. 350-361. PMid:24074964.

HOSSEINIDOUST, Z., TUFENKJI, N. and VAN DE VEN, T.G., 2013. Predation in homogeneous and heterogeneous phage environments affects virulence determinants of Pseudomonas aeruginosa. Applied and Environmental Microbiology, vol. 79, no. 9, pp. 2862-2871. PMid:23435883.

JIMÉNEZ, T., NOYOLA, A., ROMERO, R., BARRERA, R., ROMÁN, R., RAMOS, G., CARLOS, R.L.J., SANCHEZ, A. and ARADILLAS, V., 2015. Pseudomonas aeruginosa strains resistant to antibiotics and heavy metals, producing biosurfactant, pyocyanin and biofilm from surfaces hospital environment. Bothalia Journal, vol. 45 , no. 4 , pp. 36-45.

JOSE, D., JOSE, S. and SINGH, B., 2017. Prufication and characterization of higly active LasB protease from Pseudomonas aeruginosa MCCB123. Indian Journal of Experimental Biology, vol. 55, pp. 303-310.

KALAIARASAN, E. and NARASIMHA, H.B., 2016. Antimicrobial resistance patterns and prevalence of virulence factors among biofilm producing strains of Pseudomonas aeruginosa. European Journal of Biotechnology and Bioscience, vol. 4, no. 11, pp. 26-28.

KALKAN, S. and HALKMAN, K., 2006. Bacillus cereus ve içme sütünde oluşturduğu sorunlar. Orlab On-Line Mikrobiyoloji Dergisi, vol. 4, no. 1, pp. 1-11.

KEHAROM, S., MAHACHAI, R. and CHANTHAI, S., 2016. The optimization study of $\alpha$-amylase activity based on central composite design-response surface methodology by dinitrosalicylic acid method. International Food Research Journal, vol. 23, no. 1, pp. 10-17.

KESSLER, E., SAFRIN, M., OLSON, J.C. and OHMAN, D.E., 1993. Secreted LasA of Pseudomonas aeruginosa is a staphylolytic protease. The Journal of Biological Chemistry, vol. 268, no. 10 pp. 7503-7508. PMid:8463280.

KHANNOUS, L., JRAD, M., DAMMAK, M., MILADI, R., CHAABEN, N., KHEMAKHEM, B., GHARSALLAH, N. and FENDRI, I., 2014. Isolation of a novel amylase and lipase-producing Pseudomonas luteola strain: study of amylase production conditions. Lipids in Health and Disease, vol. 13, no. 9, pp. 1-9. PMid:24405763.

KONG, K.F., JAYAWARDENA, S.R., INDULKAR, S.D., DEL PUERTO, A., KOH, C.L., HØIBY, N. and MATHEE, K., 2005. Pseudomonas aeruginosa Amp R is a global transcriptional factor that regulates expression of Amp C and Pox B $\beta$ - lactamases, proteases, quorum sensing and other virulence factors. Antimicrobial Agents and Chemotherapy, vol. 49, no. 11, pp. 4567-4575. PMid:16251297.

LIU, X.D. and XU, Y., 2008. A novel raw starch digesting $\alpha$-amylase from a newly isolated Bacillus sp. YX-1: purification and characterization. Bioresource Technology, vol. 99, no. 10, pp. 4315-4320. PMid:17920264.

LO, Y.L., SHEN, L., CHANG, C.H., BHUWAN, M., CHIU, C.H. and CHANG, H.Y., 2016. Regulation of motility and phenazine pigment production by fliA is cyclic-di-GMP dependent in Pseudomonas aeruginosa PAO1. PLoS One, vol. 11, no. 5, e0155397. PMid:27175902.

MAROU, I., ABOULKACEM, A., TIMINOUNI, M. and BELHAJ, A., 2016. Virulence profiles of clinical and environmental Pseudomonas aeruginosa isolates from Central Morocco. African Journal of Microbiology, vol. 10, no. 14, pp. 473-480.

MIRANI, Z.A., FATIMA, A., UROOJ, S., AZIZ, M., KHAN, M.N. and ABBAS, T., 2018. Relationship of cell surface hydrophobicity with biofilm formation and growth rate: a study on Pseudomonas aeruginosa, Staphylococcus aureus and Escherichia coli. Iranian Journal of Basic Medical Sciences., vol. 21, no. 7, pp. 760-769. PMid:30140417.

OGUNNARIWO, J. and HAMILTON-MILLER, T., 1975. Brown- and red-pigmented Pseudomonas aeruginosa: differentiation between melanin and pyorubrin. Journal of Medical Microbiology, vol. 8, no. 1, pp. 199-203. PMid:805242.

ÖZCAN, K. and ÇORBACI, C., 2017. Streptomyces sp. K22 ve K30 suşlarından lipaz ve proteaz enzim üretimi. Karadeniz Fen Bilimleri Dergisi, vol. 7, no. 2, pp. 128-135.

PARMAR, D. and PANDYA, A., 2012. Characterization of amylase producing bacterial isolates. Bulletin of Environment, Pharmacology. Life Sciences, vol. 1, no. 6, pp. 42-47.

SARKISOVA, S., PATRAUCHAN, M.A., BERGLUND, D., NIVENS, D.E. and FRANKLIN, M.J., 2005. Calcium-induced virulence factors associated with the extracellular matrix of mucoid Pseudomonas aeruginosa biofilms. Journal of Bacteriology, vol. 187, no. 13, pp. 4327-4337. PMid:15968041.

SUNDARRAM, A. and MURTHY, T.P.K., 2014. $\alpha$-Amylase production and applications: a review. Journal of Applied and Environmental Microbiology, vol. 2, no. 4, pp. 166-175.

VENKATA, N.R.E. and DIVAKAR, G., 2013. Production of amylase by using Pseudomonas aeruginosa isolated from garden soil. International Journal of Advance Pharmaceutical and Biological Chemistry, vol. 2, no. 1, pp. 50-56.

VIJAY, A., BABU, S. and GUDLAPALLY, J., 2014. Isolation and extraction of elastase producing bacteria from natural habitat (water-soil sample) and targeting it to APP, a cause of alzheimer's disease. Helix, vol. 2, pp. 516-520.

ZHANG, Y., KONG, J., XIE, Y., GUO, Y., CHENG, Y., QIAN, H. and YAO, W., 2018. Essential oil components inhibit biofilm formation in Erwinia carotovora and Pseudomonas fluorescens via anti-quorum sensing activity. Lebensmittel-Wissenschaft + Technologie, vol. 92, pp. 133-139.

ZHENG, Y., LI, Y., LONG, H., ZHAO, X., JIA, K., LI, J., WANG, L., WANG, R., LU, X. and ZHANG, D., 2018. bifA regulates biofilm development of Pseudomonas putida MnB1 as a primary response to $\mathrm{H}_{2} \mathrm{O}_{2}$. Frontiers in Microbiology, vol. 9, pp. 1490. PMid:30042743. 